\title{
Editorial
}

Journal of Innate

Immunity
J Innate Immun 2017;9:109-110

DOI: $10.1159 / 000457176$
Published online: February 2, 2017

\section{Cells of Innate and Adaptive Immunity: A Matter of Class?}

Following the early discoveries of phagocytosis by Elie Metchnikoff, much scientific attention was focused on research related to adaptive immune mechanisms [1]. This work has solved many complex and intellectually challenging mysteries such as antigen processing, immunologic memory, and mechanisms allowing the production of specific antibodies. These achievements have also been critical for the advancement of medicine, allowing clinical breakthroughs as exemplified by vaccination and transplantation. However, the innate immunity paradigm introduced by Charles Janeway has profoundly changed our perspective on the evolution and complexity of immunological pathways [2]. Could immune cells be divided into innate and adaptive immune cells, respectively, or is this a simplistic view? In recent years, novel concepts addressing the roles for epithelial cells and innate lymphoid cells have entered the scene [3]. Evolutionarily ancient cells, such as dendritic cells, macrophages, and neutrophils, collaborate and are part of the innate immune system. However, they also execute effector functions, as per instructions from the adaptive side of immunity. One example is the recognition of immobilized IgG on invading microorganisms by $\mathrm{Fc}$ receptors on neutrophils resulting in cytotoxic activities.
In this issue, our rapidly expanding insights into the roles of innate immune cells are summarized in an interesting review by Georg Gasteiger and his colleagues [4]. The view on the neutrophil, including its recruitment to sites of inflammation, life span, and the recently discovered formation of NETs are of particular interest [5-9]. Myeloid-derived suppressor cells, MDSCs, are a relatively recently identified and heterogeneous group of immature myeloid cells of monocytic and granulocytic origin that suppress effector immune cells, mainly $\mathrm{T}$ cells and natural killer cells $[10,11]$.

The sequence of immune responses has attracted increasing attention where basic and fast cellular defense is common through evolution while slower and more specific responses appear later [12]. Macrophages are required for all animal life and possess a plethora of key immune functions, not least reflected by their M1 and M2 polarization [13-15].

In many aspects, the cells of innate immunity provide the fundament for adaptive immunity. The review by Gasteiger et al. [4] in this issue updates the current knowledge on these important players.

Heiko Herwald, Lund Arne Egesten, Lund 


\section{References}

1 Gordon S: Elie Metchnikoff, the man and the myth. J Innate Immun 2016;8:223-227.

2 Janeway CA Jr: Approaching the asymptote? Evolution and revolution in immunology. Cold Spring Harb Symp Quant Biol 1989;54: 1-13.

3 Artis D, Spits H: The biology of innate lymphoid cells. Nature 2015;517:293-301.

-4 Gasteiger G, D’Osualdo A, Schubert DA, Weber A, Bruscia EM, Hartl D: Cellular innate immunity: an old game with new players. J Innate Immun 2017;9:111-125.

5 Carevic M, Öz H, Fuchs K, Laval J, Schroth C, Frey N, Hector A, Bilich T, Haug M, Schmidt A, Autenrieth SE, Bucher K, Beer-Hammer S, Gaggar A, Kneilling M, Benarafa C, Gao JL, Murphy PM, Schwarz S, Moepps B, Hartl D: CXCR1 regulates pulmonary anti-pseudomonas host defense. J Innate Immun 2016;8: 362-373.
6 Espinasse MA, Pépin A, Virault-Rocroy P, Szely N, Chollet-Martin S, Pallardy M, BiolaVidamment A: Glucocorticoid-induced leucine zipper is expressed in human neutrophils and promotes apoptosis through Mcl-1 down-regulation. J Innate Immun 2016;8:8196.

7 Ramos MV, Mejias MP, Sabbione F, Fernandez-Brando RJ, Santiago AP, Amaral MM, Exeni R, Trevani AS, Palermo MS: Induction of neutrophil extracellular traps in Shiga toxin-associated hemolytic uremic syndrome. J Innate Immun 2016;8:400-411.

8 Giai C, Gonzalez CD, Sabbione F, Garofalo A, Ojeda D, Sordelli DO, Trevani AS, Gómez MI: Staphylococcus aureus induces shedding of IL-1RII in monocytes and neutrophils. J Innate Immun 2016;8:284-298.

-9 McCracken JM, Kinkead LC, McCaffrey RL, Allen LAH: Francisella tularensis modulates a distinct subset of regulatory factors and sustains mitochondrial integrity to impair human neutrophil apoptosis. J Innate Immun 2016;8:299-313.

10 Ost M, Singh A, Peschel A, Mehling R, Rieber N, Hartl D: Myeloid-derived suppressor cells in bacterial infections. Front Cell Infect Microbiol 2016;6:37.
Ballbach M, Hall T, Brand A, Neri D, Singh A, Schaefer I, Herrmann E, Hansmann S, Handgretinger R, Kuemmerle-Deschner J, Hartl D, Rieber N: Induction of myeloid-derived suppressor cells in cryopyrin-associated periodic syndromes. J Innate Immun 2016;8:493-506.

12 Mills CD, Ley K, Buchmann K, Canton J: Sequential immune responses: the weapons of immunity. J Innate Immun 2015;7:443-449.

13 Lin YW, Lee B, Liu PS, Wei LN: Receptor-interacting protein 140 orchestrates the dynamics of macrophage M1/M2 polarization. J Innate Immun 2016;8:97-107.

14 McClure C, Brudecki L, Yao ZQ, McCall CE, El Gazzar M: Processing body formation limits proinflammatory cytokine synthesis in endotoxin-tolerant monocytes and murine septic macrophages. J Innate Immun 2015; 572-583.

15 Bruscia EM, Bonfield TL: Cystic fibrosis lung immunity: the role of the macrophage. J Innate Immun 2016;8:550-563. 